\title{
Eksplorasi Perbedaan Gender Pada Argumentasi Ilmiah Siswa
}

\author{
Nurul Atqiya ${ }^{1}$, Lia Yuliati ${ }^{1}$, Markus Diantoro ${ }^{1}$ \\ ${ }^{1}$ Pendidikan Fisika-Universitas Negeri Malang
}

\begin{tabular}{l} 
INFO ARTIKEL \\
\hline Riwayat Artikel: \\
Diterima: $14-08-2020$ \\
Disetujui: $23-09-2020$ \\
\hline
\end{tabular}

\section{Kata kunci:}

scientific argumentation;

gender;

argumentasi ilmiah;

gender

\begin{abstract}
ABSTRAK
Abstract: Studies about neuroscience reported that women and men have differences in some parts of their brain. Women and men have different ways to encrypt memories, solve problems, and make decisions. This study aimed to explore and raise gender differences in scientific argumentation. There were 80 students (40 female and 40 male students) selected by random sampling technique from two schools in Malang. Each student was given eight essays about Newton's Law as the instrument of scientific argumentation. To analyze the data, the kruskal-wallis test was conduced $(\mathrm{P}<0.05$ was considered a significant difference). The result showed that (1) There was significant difference between male and female students' scientific argumentation; (2) Female students' were better at prividing claim, evidence, and reasoning in scientific argumentation than male students'; (3) Students' scientific argumentation were insufficient category, claim, evidence, and reasoning in level one. These findings could be used as consideration in the next study especially about learnings to improve students' scientific argumentation.
\end{abstract}

\begin{abstract}
Abstrak: Penelitian tentang neuroscience mengungkapkan bahwa laki-laki dan perempuan memiliki perbedaan di beberapa bagian otak mereka. Ada perbedaan cara dalam memproses memori, memecahkan masalah, dan membuat keputusan antara lakilaki dan perempuan. Penelitian ini bertujuan untuk mengeksplorasi perbedaan gender dalam argumentasi ilmiah. Ada 80 siswa (40 siswa laki-laki dan 40 siswa perempuan) dipilih dengan teknik purposive sampling dari dua sekolah di Malang. Setiap siswa diberi delapan esai tentang Hukum Newton sebagai instrumen argumentasi ilmiah. Uji krusial-wallis dilakukan (nilai-p $<0,05$ dianggap sebagai perbedaan yang signifikan). Hasil penelitian menunjukkan bahwa (1) terdapat perbedaan argumentasi ilmiah yang signifikan antara siswa laki-laki dan perempuan; (2) Claim, evidence, dan reasoning dalam argumentasi ilmiah yang dikemukakan siswa perempuan lebih baik daripada laki-laki; (3) argumentasi ilmiah siswa dalam kategori kurang dengan level claim, evidence, dan reasoning dalam level 1. Temuan ini dapat digunakan sebagai pertimbangan dalam studi argumentasi ilmiah berikutnya terutama pembelajaranpembelajaran yang tepat untuk meningkatkan argumentasi ilmiah siswa.
\end{abstract}

\section{Alamat Korespondensi:}

Nurul Atqiya

Pendidikan Fisika

Universitas Negeri Malang

Jalan Semarang 5 Malang

E-mail: nurulatqiya30@gmail.com
Aliran informasi yang masif di abad ke-21 menuntut setiap orang bersikap kritis terhadap setiap informasi yang diterima. Mengevaluasi bukti dan berkomunikasi secara ilmiah merupakan praktik ilmiah yang harus dibiasakan kepada siswa melalui pembelajaran sains (NGSS Lead States, 2013; NRC, 2012). Berdebat dan berkomunikasi dikatakan bersifat ilmiah jika penjelasan untuk meyakinkan orang lain telah teruji dan bukti yang dikemukakan disertai dengan proses penalaran (Lawson, 2003; Park, 2016). Mengomunikasikan pengetahuan dan berdebat dalam sains dapat dicapai jika siswa memiliki kemampuan berargumentasi ilmiah (Duschl, 2008). Guru harus membantu siswa terbiasa berargumentasi ilmiah dalam pembelajaran. Siswa harus dapat berpikir seperti seorang ilmuwan yang menggunakan argumentasi dalam mengembangkan pengetahuan ilmiahnya (Erduran et al., 2005) dan menggunakan penalaran dalam proses argumentasi (Duschl, 2008; Sampson et al., 2011). Ada tiga unsur dalam argumentasi ilmiah, yaitu claim, evidence, dan reasoning (Sampson et al., 2011). Claim adalah kesimpulan, penjelasan, atau jawaban atas pertanyaan (Sampson et al., 2011; Toulmin, 2003). Claim perlu didukung dengan evidence atau data ilmiah yang sesuai dan dibenarkan dengan reasoning (Lawson, 2003; Sampson et al., 2011; Park, 2016). Reasoning diperlukan untuk menguatkan dan membenarkan bahwa evidence yang dikemukakan layak sebagai bukti untuk mendukung claim dengan menggunakan prinsip-prinsip ilmiah yang sesuai dan memadai (Sampson et al., 2011). 
Beberapa studi mengungkapkan bahwa siswa masih perlu mengembangkan argumentasi ilmiah mereka. Di dalam eksperimen, siswa dapat membuat claim yang sesuai dengan data awal yang diperoleh, namun pada hasil eksperimen berikutnya, lebih dari 50\% siswa tidak dapat membuat claim yang tepat karena data yang diperoleh tidak konsisten dengan sebelumnya (Novak \& Treagust, 2018). Selama siswa berlatih dalam mengembangkan argumentasi ilmiah dengan pembelajaran argumentdriven inquiry, siswa belum terampil dalam mengemukakan claim dan menggunakan reasoning yang sesuai meskipun disajikan evidence yang bertentangan (Walker et al., 2019). Pada pembelajaran revised argument-driven inquiry ditemukan bahwa selama pembelajaran siswa mengalami kesulitan dalam memilih sumber referensi akademik yang cocok dan dapat diandalkan untuk mendukung claim (Songsil et al., 2019). Selain itu, Songsil et al., (2019) juga menemukan bahwa siswa perempuan lebih percaya diri dan berani dalam mengungkapkan pikirannya daripada siswa laki-laki.

Ada beberapa perbedaan antara laki-laki dan perempuan berdasarkan struktur otak. Hippocampus sebagai bagian otak yang paling berperan dalam proses belajar dan memori (Goldstein, et al., 2001) berbeda antara laki-laki dan perempuan. Perempuan memiliki hippocampus yang lebih besar daripada laki-laki (Cahill, 2006). Speck et al. (2000) mengemukakan bahwa laki-laki memiliki aktivitas yang lebih dominan di bagian otak kanan, sedangkan perempuan memiliki aktivitas yang lebih dominan di bagian otak kiri. Inilah yang menjadikan perempuan memiliki kemampuan kognitif yang lebih tinggi dibandingkan laki-laki (Weiss et al., 2006). Berdasarkan tes kefasihan verbal juga ditemukan bahwa perempuan menunjukkan hasil yang lebih baik daripada laki-laki (Weiss et al., 2006).

Sebuah penelitian melaporkan bahwa laki-laki dan perempuan menunjukkan pencapaian yang sama dan pola interaksi yang serupa didalam kelompok belajar (Webb, 1984). Penelitian lain menunjukkan bahwa tidak ditemukan hubungan gender yang konsisten dengan kepercayaan diri dan persepsi pengetahuan (Asterhan, 2018). Berdasarkan hasil PISA 2018, terdapat perbedaan gender yang signifikan dalam bidang reading, namun tidak dalam bidang mathematic dan science. Dari keseluruhan negara peserta PISA, hasil reading peserta perempuan lebih baik daripada peserta laki-laki sebanyak 30 point, hasil mathematic peserta laki-laki lebih baik daripada peserta perempuan sebanyak 5 point, sedangkan hasil science peserta perempuan lebih baik daripada peserta laki-laki sebanyak dua point (OECD, 2019). Argumentasi ilmiah juga merupakan salah satu keterampilan sebagai hasil belajar siswa, penelitian ini bertujuan untuk mengeksplorasi argumentasi ilmiah siswa dan mengidentifikasi perbedaan gender didalamnya.

\section{METODE}

Penelitian ini adalah penelitian survei dengan pendekatan deskriptif untuk mengeksplorasi argumentasi ilmiah siswa. Jenis data ialah data kuantitatif yang diperoleh dari hasil tes argumentasi ilmiah pada materi hukum Newton.

\section{Subjek Penelitian}

Subjek penelitian ini adalah siswa kelas XI jurusan sains di dua sekolah menengah atas di kota Malang, Indonesia. Jumlah sampel yaitu sebanyak 80 orang yang terdiri dari 40 siswa laki-laki dan 40 siswa perempuan. Sampel dipilih dengan teknik purposive sampling yaitu yang memenuhi kriteria sebagai berikut: siswa jurusan sains (IPA) dan sudah menempuh materi hukum Newton tentang gerak.

\section{Instrumen Penelitian}

Instrumen yang digunakan untuk mengeksplorasi argumentasi ilmiah siswa terdiri dari delapan butir soal berbentuk esai yang berisi tentang hukum Newton tentang gerak. Instrumen tersebut divalidasi dengan dua cara yaitu validasi ahli dan validasi empiris. Hasil dari validasi ahli yaitu valid dengan revisi. Adapun validasi empiris adalah dengan menguji instrumen kepada 106 responden dan diperoleh skor korelasi dari pertanyaan nomor 1 hingga 8 adalah 0.692, 0.770, 0.550, 0.413, 0.506, $0.578,0.571$, dan 0.239. Semua skor ini $<\mathrm{R}$ tabel = 0,1909 atau valid. Adapun nilai Cronbach's alpha sebesar 0.691 (reliabel).

\section{Teknik Analisis Data}

Penskoran setiap butir jawaban siswa dilakukan sesuai dengan rubrik penilaian yang memenuhi langkah argumentasi ilmiah sebagaimana ditunjukkan pada tabel 1. Skor yang diperoleh siswa kemudian dikategorikan sangat baik, baik, cukup, kurang, dan sangat kurang berdasarkan tabel 2.

Tabel 1. Rubrik Argumentasi Ilmiah

\begin{tabular}{|c|c|c|c|}
\hline \multirow{2}{*}{ Komponen } & \multicolumn{3}{|c|}{ Level } \\
\hline & 0 & 1 & 2 \\
\hline $\begin{array}{l}\text { Claim/ klaim: kesimpulan yang } \\
\text { menjawab pertanyaan }\end{array}$ & $\begin{array}{l}\text { tidak membuat claim atau membuat } \\
\text { claim yang tidak tepat }\end{array}$ & $\begin{array}{l}\text { membuat claim yang tepat namun } \\
\text { tidak lengkap }\end{array}$ & $\begin{array}{l}\text { membuat claim } \\
\text { dengan tepat dan } \\
\text { lengkap }\end{array}$ \\
\hline $\begin{array}{l}\text { Evidence/bukti: } \\
\text { Data ilmiah yang mendukung klaim. } \\
\text { Data harus sesuai dan cukup untuk } \\
\text { mendukung klaim. }\end{array}$ & $\begin{array}{l}\text { tidak memberikan bukti, atau hanya } \\
\text { menyediakan bukti namun tidak } \\
\text { tepat }\end{array}$ & $\begin{array}{l}\text { memberikan bukti yang tepat tetapi } \\
\text { kurang lengkap. atau beberapa bukti } \\
\text { tidak sesuai. }\end{array}$ & $\begin{array}{l}\text { memberikan bukti } \\
\text { yang tepat dan } \\
\text { lengkap }\end{array}$ \\
\hline
\end{tabular}


Tabel 1. Rubrik Argumentasi Ilmiah (Lanjutan)

\begin{tabular}{|c|c|c|c|}
\hline \multirow[b]{2}{*}{ Komponen } & \multirow[b]{2}{*}{$\mathbf{0}$} & \multicolumn{2}{|r|}{ Level } \\
\hline & & 1 & 2 \\
\hline $\begin{array}{l}\text { Reasoning/ penalaran: } \\
\text { Pembenaran yang menghubungkan } \\
\text { klaim dan bukti. Ini menunjukkan } \\
\text { mengapa data dianggap sebagai bukti } \\
\text { dengan menggunakan prinsip-prinsip } \\
\text { ilmiah yang tepat dan memadai. }\end{array}$ & $\begin{array}{l}\text { tidak menyertakan penalaran, } \\
\text { atau hanya menyertakan } \\
\text { penalaran namun tidak dapat } \\
\text { menghubungkan bukti dengan } \\
\text { klaim. }\end{array}$ & $\begin{array}{l}\text { hanya mengulangi bukti } \\
\text { dan menghubungkannya } \\
\text { dengan klaim. } \\
\text { mungkin termasuk } \\
\text { beberapa prinsip ilmiah, } \\
\text { tetapi tidak cukup. }\end{array}$ & $\begin{array}{l}\text { memberikan penalaran yang } \\
\text { akurat dan lengkap. mencakup } \\
\text { prinsip ilmiah yang tepat dan } \\
\text { memadai. }\end{array}$ \\
\hline
\end{tabular}

Sumber: K. McNeill \& Krajcik (2008, 2006).

Tabel 2. Kategori Argumentasi Ilmiah Siswa

\begin{tabular}{ll}
\hline Skor & Kategori \\
\hline $81-100$ & Sangat Baik \\
$61-80$ & Baik \\
$41-60$ & Cukup \\
$21-40$ & Kurang \\
$0-20$ & Sangat Kurang \\
\hline
\end{tabular}

Berdasarkan normalitas data, uji independent $t$ test dilakukan dalam menganalisis data untuk mengetahui perbedaan gender pada data argumentasi ilmiah secara keseluruhan. Sementara itu, uji kruskal-wallis dilakukan untuk mengetahui perbedaan gender pada setiap unsur di dalam argumentasi ilmiah, yaitu data claim, evidence, dan reasoning. Dalam penelitian ini, nilai-p $<0,05$ dianggap sebagai perbedaan yang signifikan.

\section{HASIL}

Argumentasi Ilmiah Siswa Secara Keseluruhan

Hasil tes argumentasi ilmiah berserta unsur-unsur didalamnya disajikan dalam bentuk statistik deskriptif pada tabel 3.

Tabel 3. Statistik Deskriptif Argumentasi Ilmiah Siswa Secara Keseluruhan

\begin{tabular}{ccccccc}
\hline & Min & Maks & Std. Deviasi & Rata-rata & Level & Kategori \\
\hline Argumentasi Ilmiah & $\mathbf{8 . 3 3}$ & $\mathbf{5 4 . 1 7}$ & $\mathbf{1 0 . 1 5 6}$ & $\mathbf{2 5 . 8 5 9}$ & & Kurang \\
\hline Claim & 18.75 & 75.00 & 11.576 & 42.188 & 1 & Cukup \\
Evidence & 6.25 & 56.25 & 12.371 & 25.859 & 1 & Kurang \\
Reasoning & 0.00 & 50.00 & 11.117 & 9.531 & 1 & Sangat kurang \\
\hline
\end{tabular}

Berdasarkan tabel 3, argumentasi ilmiah siswa masih dalam kategori kurang. Siswa mengalami kesulitan dan belum dapat mengemukakan claim, evidence, dan reasoning secara tepat dan lengkap (level 1). Hal ini dapat dilihat dari claim siswa yang berada dalam kategori cukup, evidence dalam kategori kurang, dan reasoning dalam kategori sangat kurang.

\section{Argumentasi Ilmiah Siswa Berdasarkan Gender}

Hasil tes argumentasi ilmiah terhadap 40 orang siswa laki-laki dan 40 orang siswa perempuan disajikan dalam bentuk statistik deskriptif pada tabel 4.

Tabel 4. Statistik Deskriptif Argumentasi Ilmiah Siswa Berdasarkan Gender

\begin{tabular}{lccccc}
\hline Gender & N & Min & Maks & Std. Deviasi & Rata-rata \\
\hline Siswa laki-laki & 40 & 8.33 & 54.17 & 9.788 & 22.760 \\
Siswa perempuan & 40 & 10.42 & 52.08 & 9.666 & 28.959 \\
\hline
\end{tabular}

Berdasarkan hasil uji independent $t$ test, diperoleh nilai-p $<0.05$. Hal ini menunjukkan bahwa terdapat perbedaan argumentasi ilmiah yang signifikan antara siswa laki-laki dan perempuan. Argumentasi ilmiah siswa perempuan lebih tinggi daripada siswa laki-laki. Perbandingan skor rata-rata claim, evidence, dan reasoning antara siswa laki-laki dan perempuan pada setiap butir jawaban disajikan pada gambar 1. Adapun deskripsi peringkat rata-rata masing-masing unsur argumentasi ilmiah disajikan pada tabel 5 . 


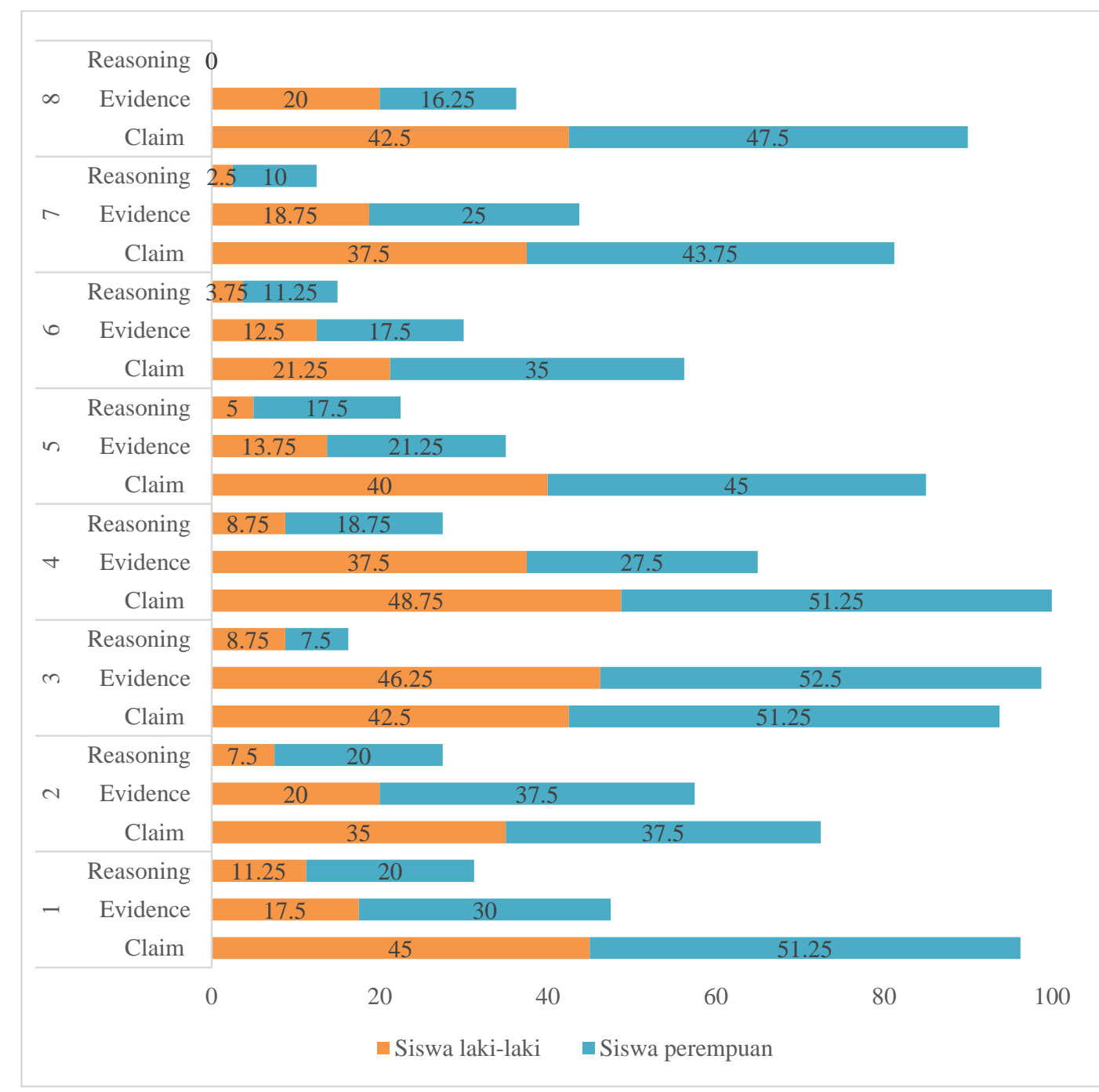

Gambar 1. Grafik Perbandingan Skor Rata-rata Claim, Evidence, dan Reasoning Siswa Laki-laki dan Perempuan

Tabel 5. Deskriptif Peringkat Rata-Rata pada Claim, Evidence, dan Reasoning Berdasarkan Gender Siswa

\begin{tabular}{lllc}
\hline & Gender & N & Mean Rank \\
\hline \multirow{2}{*}{ Skor Claim } & Siswa laki-laki & 40 & 34.13 \\
& Siswa perempuan & 40 & 46.88 \\
\hline \multirow{2}{*}{ Skor Evidence } & Siswa laki-laki & 40 & 35.35 \\
& Siswa perempuan & 40 & 45.65 \\
\hline \multirow{2}{*}{ Skor Reasoning } & Siswa laki-laki & 40 & 31.04 \\
& Siswa perempuan & 40 & 49.96 \\
\hline
\end{tabular}

Berdasarkan hasil uji kruskal-wallis pada setiap unsur argumentasi ilmiah (claim, evidence, dan reasoning), diperoleh semua nilai-p $<0.05$. Dengan demikian, terdapat perbedaan claim, evidence, dan reasoning yang signifikan antara siswa laki-laki dan perempuan. Tabel 5 menunjukkan bahwa rata-rata peringkat claim, evidence, dan reasoning siswa perempuan lebih tinggi daripada siswa laki-laki.

\section{Perbedaan Gender pada Claim Siswa}

Perbedaan yang signifikan antara claim siswa laki-laki dan perempuan berada pada butir jawaban nomor 3. Setelah dilakukan uji kruskall wallis diperoleh nilai-p<0.05 pada butir jawaban nomor 3 tersebut. Claim yang dikemukakan siswa perempuan lebih baik daripada siswa laki-laki pada butir jawaban nomor 3. Berdasarkan grafik gambar 1, skor rata-rata claim siswa perempuan adalah 51.25 sedangkan skor rata-rata claim siswa laki-laki adalah 42.5. 
Butir soal 3 berisi materi tentang Hukum II Newton, yaitu perbandingan percepatan gerobak antara berangkat dan pulang ketika gerobak didorong dengan gaya yang sama namun isi gerobak ketika berangkat masih kosong sedangkan ketika pulang isi gerobak telah penuh. Tidak ada satu pun siswa perempuan yang memberikan claim yang tidak tepat namun ada enam orang siswa laki-laki yang menyatakan bahwa lebih besar percepatan gerobak ketika pulang. Ada banyak siswa yang memberikan claim dengan sangat singkat dan kurang lengkap yaitu sebanyak 39 orang siswa perempuan dan 34 orang siswa laki-laki yang hanya menuliskan "berangkat", "ketika berangkat", atau "lebih besar berangkat" tanpa ada keterangan variabel apa yang dibandingkan. Sementara claim yang tepat dan lengkap hanya dikemukakan oleh satu orang siswa perempuan. Siswa tersebut menyatakan "Jika pemulung selalu mendorong gerobak dengan gaya yang sama, maka lebih besar percepatan gerobak ketika berangkat daripada pulang". Persentase perbedaan claim yang signifikan tersebut disajikan lebih detail pada gambar 2 .

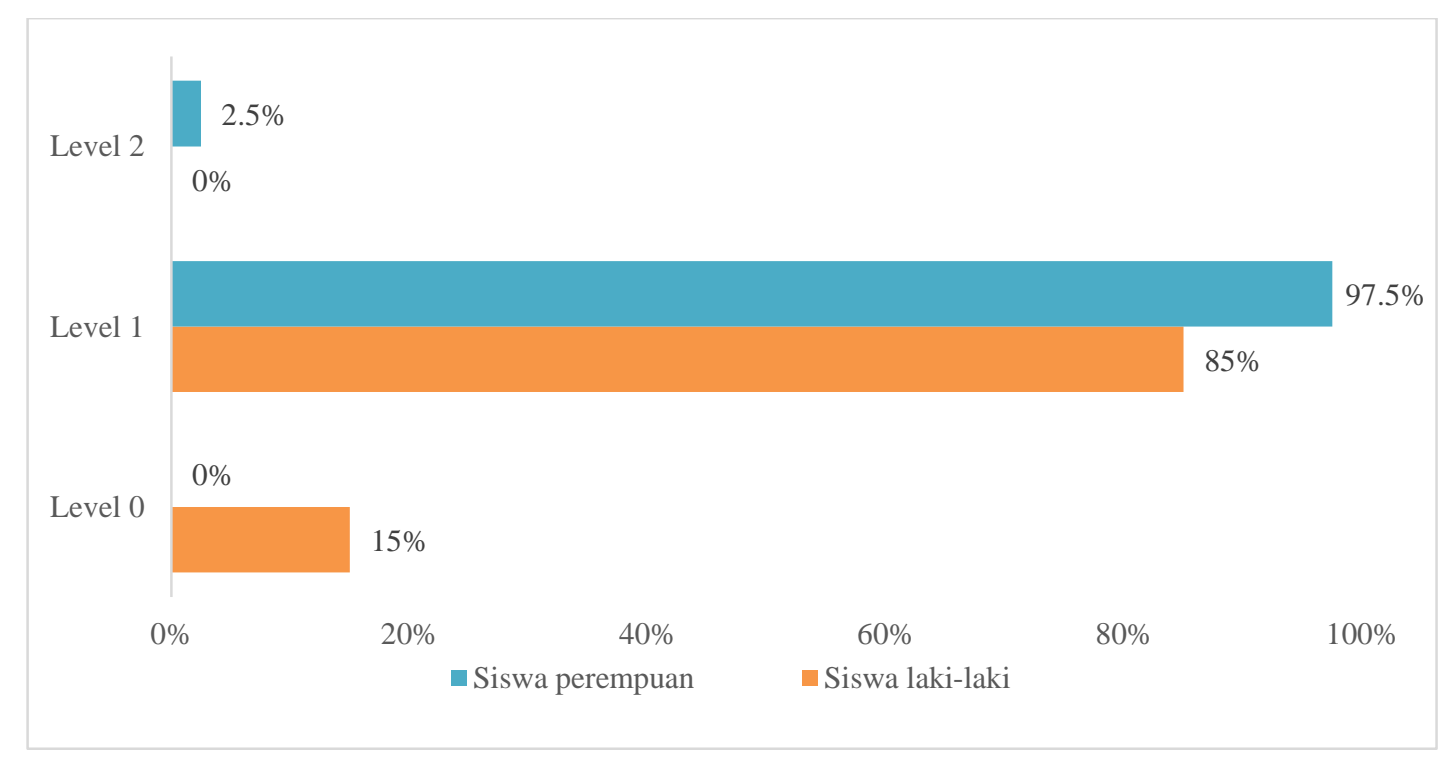

Gambar 2. Perbedaan Gender Berdasarkan Level Claim Siswa pada Butir No. 3

Grafik gambar 2 memberikan informasi sebagai berikut. Pertama, persentase siswa laki-laki yang memberikan claim yang tidak tepat (level 0) lebih banyak daripada siswa perempuan. Kedua, persentase siswa laki-laki yang memberikan claim yang tepat namun tidak lengkap (level 1) lebih sedikit daripada siswa perempuan. Ketiga, persentase siswa laki-laki yang memberikan claim yang tepat dan lengkap (level 2) lebih sedikit daripada siswa perempuan.

\section{Perbedaan Gender pada Evidence Siswa}

Setelah dilakukan uji kruskall wallis terdapat perbedaan evidence yang signifikan (nilai-p<0.05) pada butir jawaban nomor 1 dan 2, sementara butir jawaban nomor 3, 4, 5, 6, 7, dan 8 diperoleh nilai-p $>0,05$ atau tidak terdapat perbedaan yang signifikan pada nomor selain 1 dan 2. Skor rata-rata evidence yang dikemukakan siswa perempuan lebih baik daripada siswa laki-laki pada butir jawaban nomor 1 dan 2 .

Butir soal 1 berisi tentang Hukum I Newton, disajikan gambar tiga orang siswa yang berada di sebuah sepeda motor dan melaju secara cepat ketika lampu hijau setelah sebelumnya berhenti di lampu merah. Sebanyak 28 orang siswa laki-laki dan 18 orang siswa perempuan yang memberikan evidence namun tidak tepat, diantaranya ada siswa laki-laki yang mengungkapkan jatuhnya orang paling belakang karena "Kapasitas sepeda motor hanya untuk dua orang", "orang tersebut mendapat gaya gravitasi sehingga tertarik ke bumi”, "orang tersebut gagal mempertahankan kedudukannya", dan "Siswa paling belakang tidak bisa menyesuaikan keseimbangannya dengan sepeda motor secara cepat". Adapun siswa perempuan menyebutkan alasan jatuhnya orang paling belakang karena "tidak bisa menginjakkan kaki". Baik siswa laki-laki maupun perempuan juga ada yang menyatakan bahwa "benda bergerak karena diberi gaya". Siswa berpendapat bahwa sepeda motor yang melaju dengan sangat cepat memberikan gaya yang besar pada tubuh orang yang berada di atasnya. Siswa juga mengungkapkan "ada gaya reaksi yang mendorong tubuh ke belakang yang besarnya sebanding dengan gaya aksi untuk melajukan sepeda motor". Siswa perempuan menjelaskan pendapatnya dengan sebuah gambar yang berisi diagram gaya-gaya yang bekerja pada kasus melajunya sepeda motor tersebut pada gambar 1. Siswa beranggapan bahwa peristiwa jatuhnya anak dari sepeda motor disebabkan karena adanya gaya reaksi berupa gaya gesek udara dan gesek jalan yang muncul karena gaya yang mendorong sepeda motor ke arah depan. Siswa tidak berupaya menjelaskan peristiwa tersebut sesuai konsep di dalam Hukum I Newton melainkan Hukum III Newton. 


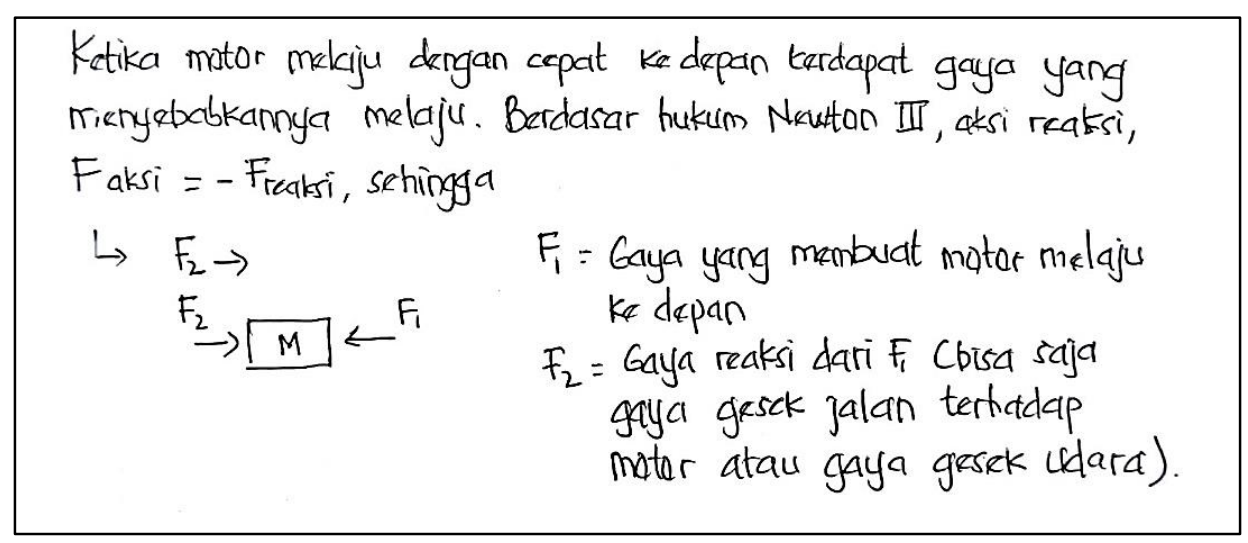

Gambar 1. Evidence yang dikemukakan Siswa pada Lembar Jawaban

Baik siswa laki-laki maupun perempuan juga ada sebagian yang dapat mengemukakan evidence yang tepat namun kurang lengkap seperti "orang yang berada di atas sepeda motor berusaha mempertahankan keadaannya", "orang paling belakang mendapat tempat duduk yang sempit", "karena posisinya paling belakang dan tidak ada yang menahan belakangnya". Hanya dua orang siswa laki-laki dan perempuan yang memberikan evidence dengan tepat yaitu "Ketika sepeda motor diam, maka badan siswa akan ikut diam. Ketika motor tiba-tiba bergerak maju, badan siswa paling belakang masih tetap diam karena sifat kelembamannya sehingga yang paling belakang bisa tertinggal".

Butir soal 2 berisi materi Hukum II Newton, sebuah gaya F dikerjakan pada benda bermassa $m_{1}$ menghasilkan percepatan $4 \mathrm{~m} / \mathrm{s}^{2}$ dan benda bermassa $m_{2}$ menghasilkan percepatan sebesar $12 \mathrm{~m} / \mathrm{s}^{2}$, kemudian bekerja pada kedua benda setelah digabung. Sebanyak 25 orang siswa laki-laki dan 15 orang siswa perempuan tidak mengemukakan evidence secara tepat, diantaranya tidak memberikan evidence, mengemukakan bahwa "besarnya $F$ dan $m$ tidak diketahui sehingga tidak bisa ditentukan", "percepatannya adalah percepatan rata-rata dari percepatan benda pertama dan kedua", serta melakukan perhitungan namun tidak tepat karena perhitungan yang dilakukan keliru atau melakukan perhitungan massa gabungan dan bukan percepatan gabungan. Adapun evidence yang tepat namun kurang lengkap dikemukakan oleh 14 orang siswa laki-laki dan 20 orang siswa perempuan, misalnya menyebutkan bahwa penambahan massa memengaruhi percepatan dan massa yang digabung menyebabkan massa benda yang didorong gaya $\mathrm{F}$ semakin besar. Namun, siswa tidak memberikan perhitungan matematis sebagai bukti bahwa percepatan yang dihasilkan lebih kecil ketika massa kedua benda digabungkan. Hanya 1 orang siswa laki-laki dan 5 orang siswa perempuan yang dapat mengemukakan evidence secara tepat dan lengkap yaitu konsep fisika beserta perhitungan matematis secara tepat untuk mendukung claim bahwa percepatan gabungan benda menjadi lebih besar daripada percepatan benda $m_{1}$ dan $m_{2}$ secara terpisah. Perbedaan yang signifikan pada evidence butir jawaban nomor 1 dan 2 disajikan dalam bentuk persentase pada grafik gambar 3. 


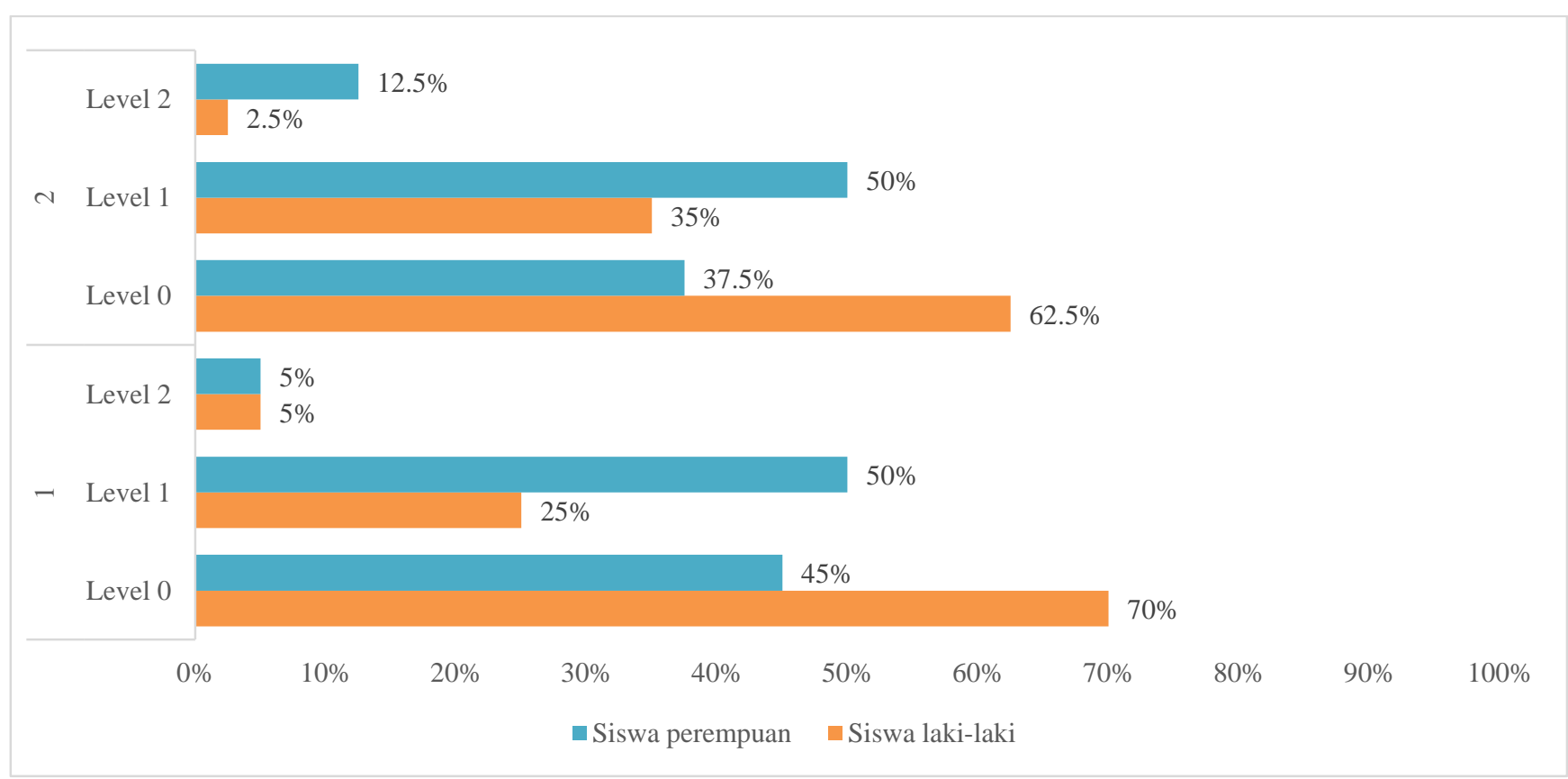

\section{Grafik 3. Perbedaan Level Evidence Siswa Berdasarkan Gender pada Butir No. 1 dan 2}

Berdasarkan grafik gambar 3, diperoleh informasi sebagai berikut. Pertama, persentase siswa yang tidak dapat memberikan evidence dengan tepat (level 0) pada butir jawaban nomor 1 dan 2 lebih banyak siswa laki-laki daripada perempuan. Kedua, persentase siswa yang dapat memberikan evidence dengan tepat namun kurang lengkap (level 1) pada butir jawaban nomor 1 dan 2 lebih banyak siswa perempuan daripada laki-laki. Ketiga, persentase siswa yang dapat memberikan evidence dengan tepat dan lengkap (level 2) pada butir jawaban nomor 1 sama antara siswa laki-laki dan perempuan, namun pada butir jawaban nomor 2 lebih banyak siswa perempuan daripada laki-laki.

\section{Perbedaan Gender pada Reasoning Siswa}

Setelah dilakukan uji kruskall wallis terdapat perbedaan reasoning yang signifikan (nilai-p<0.05) pada butir jawaban nomor 2, 4, 5 dan 7, sementara butir jawaban nomor 1, 3, 6, dan 8 diperoleh nilai-p $>0,05$ (tidak terdapat perbedaan yang signifikan). Skor rata-rata reasoning yang dikemukakan siswa perempuan lebih baik daripada siswa laki-laki pada butir jawaban nomor 2, 4, 5 dan 7. Perbedaan yang signifikan pada butir-butir jawaban tersebut dipaparkan secara lebih detail sebagai berikut.

Butir soal 2 berisi materi tentang Hukum II Newton. Sebanyak 35 orang siswa laki-laki dan 26 orang siswa perempuan tidak memberikan reasoning untuk memperkuat alasan atau evidence yang dikemukakan. Ada empat orang siswa laki-laki dan 12 orang siswa perempuan yang hanya menyebutkan bahwa kasus yang dibahas berkaitan dengan Hukum II Newton tanpa menjelaskan bagaimana Hukum II Newton dapat membenarkan bahwa bukti yang dikemukakan benar secara konsep fisika dan dapat mendukung claim. Hanya ada satu orang siswa laki-laki dan dua orang siswa perempuan yang dapat memberikan reasoning secara tepat dan lengkap yaitu "Menurut Hukum II Newton, jika massa benda diperbesar dan dikenakan gaya yang sama besar, maka percepatannya menjadi lebih kecil" dan "Hal ini sesuai dengan Hukum II Newton $\left(a=\frac{F}{m}\right)$ yaitu hubungan dengan a dan $\mathrm{m}$ berbanding terbalik".

Butir soal 4 dan 5 berisi penerapan Hukum III Newton. Butir soal 4 adalah kasus bergeraknya perahu di atas air dan butir soal 5 adalah anak-anak yang meluncur dengan sepatu roda. Pada butir soal 4, sebanyak 35 orang siswa laki-laki dan 25 orang siswa perempuan tidak memberikan reasoning apapun sedangkan tanpa reasoning pada butir soal 5 jumlah siswa lakilaki bertambah menjadi 36 orang dan siswa perempuan menjadi 26 orang. Pada butir soal 4, ada tiga orang siswa laki-laki dan 15 orang siswa perempuan yang hanya menyebutkan bahwa kasus yang dibahas berkaitan dengan Hukum III Newton tanpa menjelaskan bagaimana Hukum III Newton dapat membenarkan bahwa bukti yang dikemukakan benar secara konsep fisika dan dapat mendukung claim, seperti menyebutkan "Hal ini sesuai dengan Hukum III Newton yaitu adanya aksi reaksi". Sementara pada butir soal 5, reasoning yang tepat namun kurang lengkap dikemukakan oleh empat orang siswa laki-laki dan 14 orang siswa perempuan. Pada butir soal 4, hanya ada dua orang siswa laki-laki yang mengemukakan reasoning dengan tepat yaitu "Menurut Hukum III Newton, ketika ada gaya aksi yang dilakukan ke sebuah benda, ada gaya reaksi yang arahnya berlawanan dengan benda itu. Saat bapak itu memberikan gaya ke belakang dengan cara mendayung ke belakang maka perahu dapat melaju ke depan" dan "Kegiatan tersebut merupakan hukum III Newton dalam aplikasi kehidupan, bapak tersebut mendayung ke 
belakang (aksi). Sebagai reaksi, air memberi gaya ke depan sehingga perahu bergerak ke depan”. Adapun pada butir soal 5 tidak ada satupun siswa baik laki-laki maupun perempuan yang dapat memberikan reasoning secara tepat dan lengkap.

Butir soal 7 berisi identifikasi gaya aksi dan reaksi pada gambar dua benda yang bertumpukan. Sebanyak 38 orang siswa laki-laki dan 32 orang siswa perempuan yang tidak memberikan reasoning. Ada 2 orang siswa laki-laki dan 8 orang siswa laki-laki yang memberikan reasoning dengan tepat namun kurang lengkap atau kurang cukup untuk mendukung claim. Tak ada satu siswa pun yang memberikan reasoning secara tepat dan lengkap pada butir jawaban 7. Siswa hanya mengemukakan "Hal ini sesuai dengan Hukum III Newton" tanpa menjelaskan apa saja syarat-syarat pasangan gaya disebut pasangan aksi reaksi berdasarkan Hukum III Newton tersebut. Perbedaan yang signifikan pada reasoning butir jawaban nomor 2, 4, 5 dan 7 disajikan dalam bentuk persentase pada grafik gambar 4.

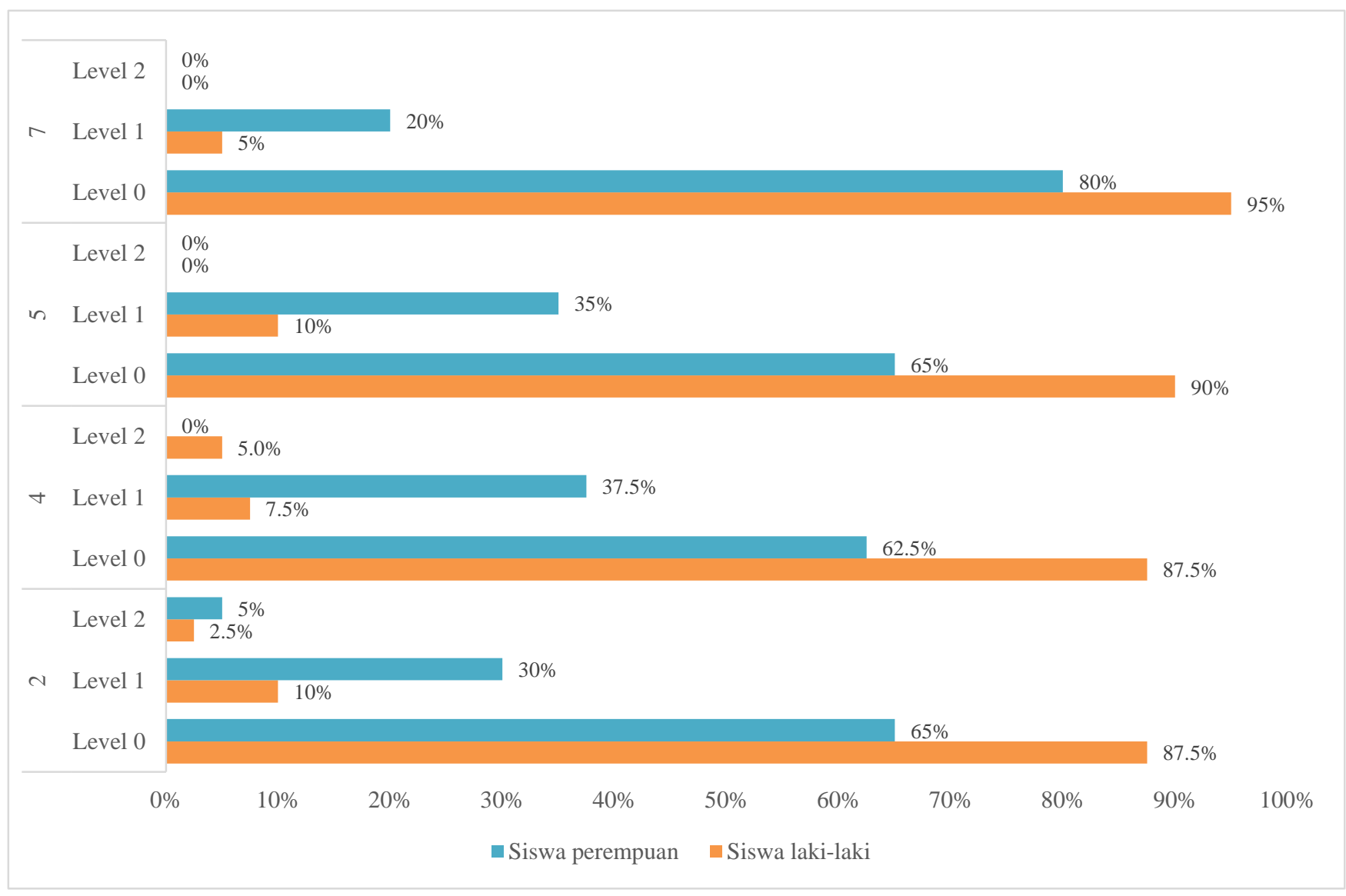

Gambar 4. Perbedaan Level Reasoning Siswa Berdasarkan Gender pada Butir No. 2, 4, 5, dan 7

Berdasarkan grafik gambar 4, diperoleh informasi sebagai berikut. Pertama, lebih banyak persentase siswa laki-laki yang tidak dapat memberikan reasoning dengan tepat (level 0) pada semua butir jawaban daripada siswa perempuan. Kedua, lebih banyak persentase siswa perempuan yang dapat memberikan evidence dengan tepat namun kurang lengkap (level 1) pada semua butir jawaban daripada siswa laki-laki. Ketiga, persentase siswa yang dapat memberikan evidence dengan tepat dan lengkap (level 2) pada butir jawaban nomor 2 lebih banyak siswa perempuan daripada laki-laki, pada butir jawaban nomor 4 lebih banyak siswa laki-laki daripada perempuan, dan jumlahnya sama antara siswa laki-laki dan perempuan pada butir jawaban nomor 5 dan 7.

\section{PEMBAHASAN}

Penelitian ini mengeksplorasi perbedaan gender dalam argumentasi ilmiah secara kuantitatif dengan memberikan instrumen soal berisi materi Hukum Newton. Terdapat perbedaan argumentasi ilmiah yang signifikan antara siswa laki-laki dan perempuan. Dalam penelitian ini diungkapkan bahwa argumentasi ilmiah siswa perempuan lebih baik daripada siswa laki-laki. Faize et al., (2017) menggambarkan argumentasi ilmiah sebagai pemecahan masalah. Strategi pemecahan masalah berbeda antara wanita dan pria (Speck et al., 2000). 
Claim yang dikemukakan siswa perempuan lebih baik daripada siswa laki-laki. Kebanyakan siswa laki-laki hanya memberikan jawaban yang sangat singkat tanpa repot berusaha memperjelasnya dengan informasi-informasi penting seperti variabel-variabel apa yang dibicarakan dan bagaimana keadaannya. Berbeda dengan siswa laki-laki, siswa perempuan memberikan claim secara lebih detail terhadap apa yang sedang berusaha mereka ungkapkan. Terkait kebiasaan menulis ini, Byrne \& Findlay (2004) mengungkapkan bahwa wanita cenderung mengetik lebih banyak SMS sebagai bentuk komunikasi secara tertulis daripada pria, sedangkan pria lebih memilih kegiatan yang lebih simple dalam berkomunikasi yaitu via telepon. Caspi et al. (2008) juga menemukan perempuan lebih aktif dan banyak menuliskan pesan pada seminar berbasis web. Perihal kebiasaan menulis, Pajares \& Valiante (2001) mengemukakan bahwa kegiatan menulis adalah kegiatan yang umumnya dilakukan oleh perempuan merupakan bentuk pandangan/orientasi gender. Namun, penelitian neuroscience menunjukkan bahwa wanita memang memiliki kinerja memori yang lebih baik daripada pria, hal itu dikaitkan dengan kinerja yang lebih baik daripada tes kefasihan verbal (Weiss et al., 2006).

Evidence yang dikemukakan siswa perempuan juga lebih baik daripada laki-laki pada penelitian ini. Evidence yang dikemukakan siswa perempuan lebih bersifat ilmiah dan berhubungan dengan konteks yang sedang dibahas, namun kurang lengkap untuk mendukung claim. Berbeda dengan siswa perempuan, siswa laki-laki memberikan bukti yang lebih bervariasi namun tidak ilmiah dan tidak tepat dalam mendukung claim. Pria memiliki aktivitas otak yang lebih tinggi di belahan hemisfer kanan (Speck et al., 2000), hal ini dapat menjadi salah satu penyebab variasi jawaban laki-laki lebih banyak dibandingkan perempuan karena kemampuannya dalam berimajinasi lebih banyak daripada perempuan.

Evidence lain yang menjadi sorotan dalam penelitian ini yaitu pembuktian secara ilmiah yang dikemukakan untuk mendukung claim yang berkaitan dengan perhitungan secara matematis. Kebanyakan siswa laki-laki hanya menuliskan bukti secara singkat dan sederhana tanpa melakukan perhitungan yang menunjukkan nilai yang diperoleh sesuai dengan claim yang diberikan. Hanya satu orang siswa laki-laki dan lima orang siswa perempuan yang dapat mengemukakan evidence secara tepat dan lengkap yaitu konsep fisika beserta perhitungan matematis secara tepat. Wanita memiliki aktivasi yang secara statistik jauh lebih tinggi di belahan hemisfer kiri (Speck et al., 2000) dan memiliki hippocampus yang lebih besar (Cahill, 2006) yaitu wilayah otak yang paling berkaitan dengan pembelajaran dan ingatan (Goldstein et al., 2001). Hal ini memungkinkan siswa perempuan dapat melakukan perhitungan matematis lebih baik daripada laki-laki di dalam penelitian ini. Sebuah studi juga menunjukkan bahwa skor tugas kognitif pada wanita jauh lebih tinggi daripada pria (Weiss et al., 2006).

Reasoning yang digunakan untuk membenarkan evidence dalam penelitian ini juga diketahui memiliki perbedaan gender yang signifikan. Reasoning yang dikemukakan siswa perempuan lebih baik daripada siswa laki-laki. Siswa perempuan lebih banyak menuliskan prinsip ilmiah yang berhubungan dengan pernyataan yang dibahas daripada laki-laki. Hal ini mirip dengan temuan (Asterhan et al., 2012) bahwa kelompok perempuan memiliki skor lebih tinggi dalam kompleksitas argumen daripada kelompok laki-laki. Semua siswa perempuan memberikan lebih banyak reasoning dan argumen dua sisi daripada siswa laki-laki (Felton et al., 2015).

Meskipun argumentasi ilmiah siswa perempuan lebih baik daripada laki-laki, secara keseluruhan argumentasi ilmiah siswa masih dalam kategori kurang. Hanya claim di dalam argumentasi ilmiah dalam kategori cukup, sedangkan evidence yang dikemukakan siswa untuk mendukung claim dalam kategori kurang dan pembenaran bahwa evidence tersebut benar-benar dapat mendukung claim (reasoning) dalam kategori sangat kurang. Siswa cenderung hanya mengemukakan jawaban singkat tanpa proses argumentasi yaitu sekedar menyatakan claim (Rahman et al., 2018). Siswa mengalami kesulitan dalam memilih sumber referensi akademik yang cocok dan dapat diandalkan untuk mendukung claim (Songsil et al., 2019). Oleh sebab itu, argumentasi ilmiah siswa masih perlu dikembangkan dan dilatih melalui pembelajaran yang tepat.

Beberapa faktor yang dapat menyebabkan rendahnya argumentasi ilmiah siswa adalah sebagai berikut. Pertama, penyebabnya dapat diasumsikan karena kemampuan siswa dalam membuat evidence dan reasoning seperti yang dijelaskan sebelumnya. Siswa tidak memberikan evidence dan reasoning yang cukup. Semakin banyak jumlah deskripsi, elaborasi/contoh untuk mendukung claim, semakin baik nilai argumentasi (Chang \& Chiu, 2008). Kedua, ini disebabkan oleh kurangnya keakraban dan pemahaman siswa terhadap konten yang terlibat dalam interaksi argumentatif (Grooms et al., 2018). Ketiga, siswa tidak mendapatkan banyak kesempatan dalam mengartikulasikan reasoning untuk claim atau keputusan untuk membenarkan jawaban mereka (Faize et al., 2017). Keempat, kurangnya pengetahuan siswa sebelumnya dan pengalaman konten khusus (von Aufschnaiter et al., 2008).

\section{SIMPULAN}

Argumentasi ilmiah menjadi salah satu kemampuan yang harus dimiliki dan dikuasai siswa di abad ke-21 ini. Penelitian ini menemukan bahwa argumentasi ilmiah siswa pada materi Hukum Newton tentang gerak masih dalam kategori kurang. Claim, evidence, dan reasoning sebagai unsur penyusun argumentasi ilmiah yang dikemukakan siswa juga masih dalam level 1, yaitu tepat namun masih kurang lengkap. Teridentifikasi claim siswa dalam kategori cukup, evidence dalam kategori kurang, dan reasoning dalam kategori sangat kurang. Terdapat perbedaan gender yang signifikan di dalam argumentasi ilmiah. Argumentasi ilmiah siswa perempuan lebih baik daripada siswa laki-laki, baik dalam unsur claim, evidence, maupun reasoning. Temuan ini dapat digunakan sebagai pertimbangan dalam studi argumentasi ilmiah berikutnya terutama pembelajaranpembelajaran yang tepat untuk meningkatkan argumentasi ilmiah siswa. 


\section{DAFTAR RUJUKAN}

Asterhan, C. S. C. (2018). Exploring Enablers and Inhibitors of Productive Peer Argumentation: The Role of Individual Achievement Goals and of Gender. Contemporary Educational Psychology, 54, 66-78. https://doi.org/10.1016/j.cedpsych.2018.05.002

Asterhan, C. S. C., Schwarz, B. B., \& Gil, J. (2012). Small-Group, Computer-Mediated Argumentation in Middle-School Classrooms: The Effects of Gender and Different Types of Online Teacher Guidance: Teacher Guidance and Gender in E-Argumentation. British Journal of Educational Psychology, 82(3), 375-397. https://doi.org/10.1111/j.20448279.2011.02030.x

Byrne, R., \& Findlay, B. (2004). Preference for SMS Versus Telephone Calls in Initiating Romantic Relationships. Australian Journal of Emerging Technologies and Society, 2(1), 48-61.

Cahill, L. (2006). Why Sex Matters for Neuroscience. Nature Reviews Neuroscience, 7(6), 477-484. https://doi.org/10.1038/nrn1909

Caspi, A., Chajut, E., \& Saporta, K. (2008). Participation in Class and in Online Discussions: Gender Differences. Computers \& Education, 50(3), 718-724. https://doi.org/10.1016/j.compedu.2006.08.003

Chang, S., \& Chiu, M. (2008). Lakatos' Scientific Research Programmes as a Framework for Analysing Informal Argumentation about Socio-scientific Issues. International Journal of Science Education, 30(13), $1753-1773$. https://doi.org/10.1080/09500690701534582

Duschl, R. (2008). Science Education in Three-Part Harmony: Balancing Conceptual, Epistemic, and Social Learning Goals. Review of Research in Education, 32(1), 268-291. https://doi.org/10.3102/0091732X07309371

Erduran, S., Osborne, J., \& Simon, S. (2005). The Role of Argumentation in Developing Scientific Literacy. In Research and the Quality of Science Education (pp. 381-394). Springer.

Faize, F. A., Husain, W., \& Nisar, F. (2017). A Critical Review of Scientific Argumentation in Science Education. Eurasia Journal of Mathematics, Science and Technology Education. https://doi.org/10.12973/ejmste/80353

Felton, M., Crowell, A., \& Liu, T. (2015). Arguing to Agree: Mitigating My-Side Bias Through Consensus-Seeking Dialogue. Written Communication, 32(3), 317-331. https://doi.org/10.1177/0741088315590788

Goldstein, J. M., Seidman, L. J., Horton, N. J., Makris, N., Kennedy, D. N., Caviness, V. S., Faraone, S. V., \& Tsuang, M. T. (2001). Normal Sexual Dimorphism of the Adult Human Brain Assessed by In Vivo Magnetic Resonance Imaging. Cerebral Cortex, 11(6), 490-497. https://doi.org/10.1093/cercor/11.6.490

Grooms, J., Sampson, V., \& Enderle, P. (2018). How Concept Familiarity and Experience with Scientific Argumentation are Related to the Way Groups Participate in an Episode of Argumentation. Journal of Research in Science Teaching, 55(9), 1264-1286. https://doi.org/10.1002/tea.21451

Lawson, A. (2003). The Nature and Development of Hypothetico-Predictive Argumentation with Implications for Science Teaching. International Journal of Science Education, 25(11), 1387-1408. https://doi.org/10.1080/0950069032000052117

McNeill, K., \& Krajcik, J. (2008). Assessing Middle School Students' Content Knowledge and Reasoning Through Written Scientific Explanations. Assessing Science Learning: Perspectives from Research and Practice, 101-116.

McNeill, K. L., Lizotte, D. J., Krajcik, J., \& Marx, R. W. (2006). Supporting Students' Construction of Scientific Explanations by Fading Scaffolds in Instructional Materials. Journal of the Learning Sciences, 15(2), 153-191. https://doi.org/10.1207/s15327809j1s1502_1

NGSS Lead States. (2013). Next Generation Science Standards: For States, By States. The National Academies Press.

Novak, A. M., \& Treagust, D. F. (2018). Adjusting Claims as New Evidence Emerges: Do Students Incorporate New Evidence into their Scientific Explanations? Journal of Research in Science Teaching, 55(4), 526-549. https://doi.org/10.1002/tea.21429

OECD. (2019). Girls' and Boys' Performance in PISA. In OECD, PISA 2018 Results: Vol. II. OECD. https://doi.org/10.1787/f56f8c26-en

Pajares, F., \& Valiante, G. (2001). Gender Differences in Writing Motivation and Achievement of Middle School Students: A Function of Gender Orientation? Contemporary Educational Psychology, 26(3), 366-381. https://doi.org/10.1006/ceps.2000.1069

Park, S. K. (2016). Exploring the Argumentation Pattern in Modeling-based Learning about Apparent Motion of Mars. Eurasia: Journal of Mathematics, Science \& Technology Education, 12(1). https://doi.org/10.12973/eurasia.2016.1423a

Rahman, A., Diantoro, M., \& Yuliati, L. (2018). Kemampuan Argumentasi Ilmiah Siswa pada Hukum Newton di Sekolah Menengah Atas. Jurnal Pendidikan: Teori, Penelitian, dan Pengembangan, 3(7), 903-911.

Ruigrok, A. N. V., Salimi-Khorshidi, G., Lai, M.-C., Baron-Cohen, S., Lombardo, M. V., Tait, R. J., \& Suckling, J. (2014). A Meta-Analysis of Sex Differences in Human Brain Structure. Neuroscience \& Biobehavioral Reviews, 39, 34-50. https://doi.org/10.1016/j.neubiorev.2013.12.004

Sampson, V., Grooms, J., \& Walker, J. P. (2011). Argument-Driven Inquiry as a Way to Help Students Learn How to Participate in Scientific Argumentation and Craft Written Arguments: An Exploratory Study. Science Education, 95(2), 217-257. https://doi.org/10.1002/sce.20421 
Songsil, W., Pongsophon, P., Boonsoong, B., \& Clarke, A. (2019). Developing Scientific Argumentation Strategies Using Revised Argument-Driven Inquiry (rADI) in Science Classrooms in Thailand. Asia-Pacific Science Education, $5(1), 7$. https://doi.org/10.1186/s41029-019-0035-x

Speck, O., Ernst, T., Braun, J., Koch, C., Miller, E., \& Chang, L. (2000). Gender Differences in the Functional Organization of the Brain for Working Memory: NeuroReport, 11(11), 2581-2585. https://doi.org/10.1097/00001756-200008030-00046

Toulmin, S. E. (2003). The Uses of Argument: Updated Edition (2nd ed.). Cambridge University Press. https://doi.org/10.1017/CBO9780511840005

von Aufschnaiter, C., Erduran, S., Osborne, J., \& Simon, S. (2008). Arguing to Learn and Learning to Argue: Case Studies of How Students' Argumentation Relates to Their Scientific Knowledge. Journal of Research in Science Teaching, 45(1), 101-131. https://doi.org/10.1002/tea.20213

Walker, J. P., Van Duzor, A. G., \& Lower, M. A. (2019). Facilitating Argumentation in the Laboratory: The Challenges of Claim Change and Justification by Theory. Journal of Chemical Education, 96(3), 435-444. https://doi.org/10.1021/acs.jchemed.8b00745

Webb, N. M. (1984). Sex Differences in Interaction and Achievement in Cooperative Small Groups. Journal of Educational Psychology, 76(1), 33-44. https://doi.org/10.1037/0022-0663.76.1.33

Weiss, E. M., Ragland, J. D., Brensinger, C. M., Bilker, W. B., Deisenhammer, E. A., \& Delazer, M. (2006). Sex Differences in Clustering and Switching in Verbal Fluency Tasks. Journal of the International Neuropsychological Society, 12(04). https://doi.org/10.1017/S1355617706060656

Xin, J., Zhang, Y., Tang, Y., \& Yang, Y. (2019). Brain Differences Between Men and Women: Evidence from Deep Learning. Frontiers in Neuroscience, 13. https://doi.org/doi: 10.3389/fnins.2019.00185 